\title{
Perancangan Influence Diagram Perhitungan Dampak Dari Revolusi Industri 4.0 Terhadap Pengangguran Kerja
}

\author{
Rio Aurachman ${ }^{1, *}$ \\ 1 Universitas Telkom, Bandung \\ *E-mail:rioaurachman@telkomuniversity.ac.id
}

\begin{abstract}
Abstrak
Revolusi Industri 4.0 diperkirakan akan memberikan dampak Terhadap Ketenagakerjaan, khususnya pengangguran kerja. Hal yang menjadi tujuan dari penelitian ini adalah mendapatkan pemahaman kaitan antara variabel di dalam sistem yang mengalami transisi teknologi Industri 4.0 agar dapat dilakukan antisipasi dampak-dampak perkembangan teknologi, khsuusnya pada bidang pengangguran kerja. (2) Penelitian dilakukan dengan melakukan proses pengembangan model matematika, khususnya pada fase model konseptual, menggunakan pendekatan sistem berdasarkan berbagai literatur yang menunjang.Didapatkan hasil bahwa variabel yang dapat dipertimbangan dalam pengambilan keputusan adalah tingkat keterbukaan terhadap teknologi, tingkat pelatihan terkait Industry 4.0 dan tingkat pelatihan untuk model bisnis baru.Kaitan model tersebut dijelaskan menggunakan Influence Diagram. Influence diagram yang dirancang ini dapat menjadi dasar untuk merancang model matematika dan merancang model simulasi. Pendekatan sistem dan management science dalam perumusan kaitan variabel yang telah disebut, menjadi cara baru yang dapat memberikan alternatif solusi atas permasalahan.
\end{abstract}

Kata Kunci : Industri 4.0, Influence Diagram, Model matematika, Pendekatan Sistem,

Pendahuluan

Dengan adanya perubahan sistem industri, maka jugaakan terjadi perubahan dalam komponen-komponen di dalam sistem industri tersebut. Di dalam sistem industri tersebut, antara bisnis yang satu dan bisnis yang lain.antara model bisnis yang satu dan model bisnis yang lain, melakukan proses yang berkesinambungan, saling melengkapi. Dengan bergantinya peran dan proses yang dilakukan oleh manusiauntuk kemudian dilakukan oleh mesin akan mengubah tingkat kebutuhan akan manusia dan kebutuhan akan mesin tersebut. Kebutuhan industri terhadap manusia akan berkurang serta kebutuhan industri terhadap mesin akan bertambah. Dalam model Bisnis kanvas[1], salah satu komponen penting penyusunan model bisnis salah key resource. Key resource yang pada situasi sebelumnya adalah manusia, akan berubah menjadi digantikan oleh mesin dan smart system. Dikarenakan key resource tersebut berubah, tentu sumber daya pendukungnya pun berubah. Ketika manusia menjadi key resource, proses mengelola manusia menjadi penting namun ketika mesin menjadi sumber dayanya pengelola mesin menjadi penting.Ini adalah salah satu efek perubahan model bisnis yang mana terlihat dampaknya terhadap kebutuhan tenaga kerja.

Perubahan model bisnis ini dapat dilakukan prediksinya dengan cara membedah dan mengkaji setiap proses di dalam sistem industri. Kemudian proses demi proses diteliti dan dikaji. Revolusi Industri 4.0 menyisakan beberapa potensi tapi sekaligus juga masalah. Pabrik-pabrik akan cenderung menggunakan sistem yang lebih otomatis. Pergantian perilaku ini akan menggantikan peran manusia dalam proses produksi. Efek dari sistem otomatis ini dapat menciptakan banyak pemutusan hubungan kerja[2]. Masyarakat dan peneliti memerlukan sebuah strategi untuk dapat menyelesaikan permasalahan ini. 
Diperlukan sebuah panduan bagi pemangku kepentingan dalam mengambil keputusan yang mengantisipasi permasalahan pengangguran tersebut.Pemerintah dapat memutuskan untuk mengadopsi teknologi secara penuh atau menolak teknologi tersebut sementara waktu.Pemerintah dan masyarakat juga dapat melakukan antisipasi dengan Pendidikan dan pelatihan sehingga sumber daya manusia dapat tetap bekerja dengan sistem industri baru akibat teknologi baru.Pengembangan manusia dan perkembangan teknologi bagaikan melakukan semacam balapan mana yang lebih cepat.Bila pengembangan manusia terlambat, dapat menimbulkan ketidaksiapan kerja dan pengangguran. Dibutuhkan sebuah model matematika yang memandu proses pengambilan keputusan tersebut dan mempelajari kaitannya secara lebih akurat. Melalui riset yang terpadu, dapat ditemukan model matematika yang mampu menghitung kebutuhan lapangan kerja baru akibat dari proses pemutusan hubungan kerja ini serta apa bentuk antisipasi yang dapat dilakukan.

Beberapa literatur dan penelitian yang mendukung penelitian ini meliputi pembahasan kaitan antara ketenagakerjaan dan perkembangan teknologi.Terdapat fakta bahwa sejak dahulu, masyarakat selalu mengaitkan antara pengangguran dan perkembangant teknologi [3][2].Namun pada saat itu sulit dibangun argumen yang kuat. Hal itu disebabkan para ahli ekonomi belum memiliki teori yang siap pakai untuk menjelaskan hal tersebut[3]. Dikembangkan beberapa model untuk menghitung kaitan antara pengangguran dan teknologi, salah satunya mempelajari critical point dari penggunaan teknologi dan pengaruhnya terhadap equilibrium tingkat pengangguran[4].Terdapat pula riset yang mempertimbangkan aspek ekonomi makro dalam perhitungan tingkat pengangguran dan perkembangan teknologi[5].

Penelitian pada tahun 1990an mengungkapkan kaitan yang jelas antara perkembangan teknologi dan tingkat pengangguran [6]. Fakta tersebut juga divalidasi oleh penelitian pada tahun 2017 yang mengatakan kaitan antara perkembangan teknologi dan tingkat pengangguran [7]. Pada 1983, Upjohn institute for Employment Research melakukan perhitungan bahwa keahdiran 50.000 hingga 100.000 robot di industri di Amerika Serikat pada 1990, menimbulkan penghilangan lapangan pekerjaan sejumlah 100.000 [2]. Pada penelitian 2017 ditemukan bahwa perkembangan teknologi yang breaktrough memiliki kontribusi unemployment dalam jangan waktu panjang [8]. Hal itu divalidasi dengan fakta dalam rentang waktu 1990an, terjadi penurunan tingkat gaji dari pekerjaan keterampilan rendah. Dan dalam rentang waktu 1990an, di Eropa, terjadi peningkatkan pengangguran[9][10]. Dalam sudut pandang yang berbeda, terdapat pula pembahasan tentang efek sebaliknya yaitu, pengangguran yang tinggi dapat menghambat penggunaan teknologi [11].

Penelitian terkini mulai mempetimbangkan aspek selain otomasi mesin yang mekanistik, namun juga smart system yang akan menggantikan peran pekerjaan berketerampilan tinggi sebagaimana dapat dilihat pada [12].

\section{Metode Penelitian}

Pengembangan model influence diagram dapat dilakukan berdasarkan alur pengembangan model matematika[13].Tahapan untuk merancang model matematika diawali dengan melihat permasalahan yang nyata yang ada di dalam sebuah sistem kajian kita. Tahapan berikutnya adalah mengimplementasikan system approach untuk lalu memperoleh point of view yang menyeluruh dan menerapkan sudut pandang helicopter. System thinking membantu untuk memperoleh solusi yang optimal secara global dan tidak terjebak dalam sudut pandang yang sempit dengan solusi yang tidak optimal.[14]

Sesudah menerapkan pendekatan sistem, dapat dirancang tujuan dan permasalahan yang mana untuk dituntaskan dan dapat pula ditentukan karakterisasi sistem. Diagram yang sesuai untuk diterapkan dalam mencitrakan hal gambaran sistem, salah satunya dapat menggunakan influence diagram [15]

Proses setelahnya yaitu membuat model matematika berlandaskan dari influence diagram yang telah dibuat. Sesudah model matematika diciptakan, tahapan berikutnya yaitu menerapkan analisis, validasi, dan verifikasi. Metode validasi yang dapat diterapkan yaitu menguji hubungan yang tertuang pada influence diagram, apakah tercitrakan pada model matematika. Verifikasi dapat dijalankan menggunakan metode pengujian satuan persamaan pada model matematika, ruas kiri dan ruas kanan nya, memiliki satuan yang sama. [14] 
Validasi dan verifkasi memberikan informasi apakah model yang diterapkan sudah sesuai atau masih perlu dikembangkan dan diperbaiki sehingga cukup relevel dengan sistem yang dikaji. Proses ini dijalankan secara iteratif dan berulang hingga kriteria dapat tercapai. Setelah proses iteratif terjadi maka tahap terakhir adalah terbentuknya model matematika yang tepat sehingga bisa digunakan dalam penyelesaian permasalahan [14]

\section{Hasil Penelitian}

Beberapa variabel yang penting dan secara kuat berperan pada perhitungan model ini adalah variabel yang mengukur seberapa cepat atau seberapa banyak angkatan kerja dapat dilatih untuk melaksanakan peran industri yang baru dalam konteks otomatisasi industri. Variabel lainnya adalah seberapa cepat perubahan kebutuhan akan manusia digantikan oleh mesin. Kedua variabel ini seperti saling berkejaran dapat memberikan efek yang berbeda. Bila perkembangan teknologi lebih cepat dari proses pelatihan angkatan kerja, maka angka pengangguran akan meningkat drastis. Namun bila pendidikan dan Pelatihan angkatan kerja dapat secara cepat merespon kebutuhan tenaga kerja yang baru, maka pengangguran dapat dicegah. Bila proses pengembangan sumber daya manusia lebih cepat dibandingkan variabel perkembangan teknologi, maka tidak akan terjadi pengangguran yang besar. Meskipun Teknologi tersebut mengkonversi kebutuhan manusia menjadi dipenuhi oleh mesin, tidak akan mengancam kondisi pasar tenaga kerja,

Di sisi lain jumlah kebutuhan akan lapangan kerja baru juga dipengaruhi oleh proses inovasi dan pengembangan usaha yang dilakukan oleh para entrepreneur. Para pelaku usaha yang bertindak secara inovatif akan dapat menciptakan lapangan usaha baru yang tentunya diisi oleh angkatan kerja baru. Lapangan kerja tersebutdapat pula diisi oleh angkatan kerja lama yang tersisihkan oleh mesin dan smart system.Sebagai contoh adalah kasus berkembangnya Inovasi dan entrepreneurship dalam bidang transportasi onlineyang menciptakan banyak lapangan kerja baru di bidang programming dan pengembangan aplikasi perangkat lunak.Ini adalah tantangan bagi masyarakat untuk dapat melatih anggota masyarakat sehingga mampu memenuhi kebutuhan tenaga kerja baru di lini bisnis transportasi online ini.Namun ternyata terjadi kesenjangan dan terjadi kegagalan dari masyarakat untuk memenuhi lapangan kerja baru ini.Sehingga lini Bisnis transportasi online masih mengandalkan programmer dari luar. Kita dapat melihat bahwa kecepatan dari proses pendidikan dan pengajaran mempunyai peran penting dalam hadapi revolusi industri keempat ini.

Industry 4.0 menciptakan sistem industri dan perubahan rantai nilai. Perubahan Rantai nilai dan perubahan sistem industri ini berakibat kepada perubahan model-model bisnis yang akan muncul dan berperan. Inovasi-inovasi perlu muncul dan menyesuaikan dengan perubahan model bisnis baru dalam sistem industri baru. Dengan meningkatnya kebutuhan akan otomasi dari berbagai proses industri manufaktur dan industri jasa, akan menyebabkan meningkatnya kebutuhan manusia yang mampu merancang sistem tersebut. Selain terjadi peningkatan jumlah model bisnis yang baru, dapat pula terjadi peningkatan ukuran dari model bisnis yang sudah ada.Model bisnis dan bisnis tersebut menciptakan peningkatan Kebutuhan sumber daya manusia. Peningkatan ini dapat menciptakan lapangan kerja baru yang akan diisi oleh limpahan pekerja hasil pemutusan hubungan kerja akibat otomasi berbagai proses di dalam lingkungan industri. Diperlukan sebuah metode untuk memetakan,mengukur, dan mempersiapkan perubahan-perubahan ini sehingga dapat mencegah resiko resiko dan dampak sosial akibat perubahan besar ini.

Lembaga pendidikan,perlu dapat berperan mengelola pengetahuan yang dibutuhkan era industri 4.0. Kerjasama dan hubungan antara industri dan lembaga pendidikan perlu mengalami intensifikasi sehingga lembaga pendidikan akan mensuplai lulusan-lulusan yang memang dibutuhkan oleh industri. Hal ini sudah disadari sejak lama bahkan sebelum era industry 4.0 hadir.Namun dikala perubahan demikian cepat terjadi, komunikasi dan berbagi informasi antara industri dan lembaga pendidikan dibutuhkan lebih cepat lagi dari yang sudah ada. Perkembangan teknologi informasi yang ada pun menunjang proses pendidikan pelatihan dan pengajaran menjadi lebih efisien. Dalam waktu singkat dan biaya yang murah, suatu kompetensi dapat dimiliki oleh peserta didik. Dengan trend MOOC (massive open online course), peserta didik dapat menerima peningkatan kompetensi secara masal dan terbuka. 
Variabel-variabel tersebut saling berkaitan dan berpengaruh.Pengaruh dan kaitan tersebut dapat dipetakan menggunakan pendekatan sistem.Kaitan antara variable secara matematis dapat digambarkan menggunakan beberapa pilihan diagram. Pilihan diagram tersebut digunakan sesuai dengan keperluan, keunggulan, dan kebutuhan. Beberapa alternatif diantaranya adalah menggunakan influence diagram, causal loop diagram, stock flow diagram, dan diagram lainnya. Bentuk diagram sederhana yang dapat memperjelas kaitan antara variable tersebut adalah influence diagram.Diagram tersebut mengaitkan hubungan antara variable yang digambarkan dengan beberapa icon unik. Keunggulan influence diagram adalah dapat membedakan antara input yang dapat dikendalikan dan input yang tidak dapat dikendalikan. Hal ini bermanfaat bila pemodel ingin membuat model versi sederhana yang fokus pada sub sistem tertentu. Sistem yang lebih luas diperlukan sebagai input yang tidak bisa dikendalikan (uncontrollable input).

Berdasarkan pendataan variabel-variabel serta mempelajari beberapa kaitannya secara logis dan berdasarkan studi literatur, maka didapatkan Influence Diagram sebagai berikut.Gambar 1adalah influence diagram yang telah dirancang. Variabel-variabel yang terlibat dalam model matematika dirangkum pada tabel berikut:

Tabel 1. Variabel Model Matematika

\begin{tabular}{|l|l|}
\hline Variabel & \multicolumn{1}{|c|}{ Penjelasan } \\
\hline Utotal & Jumlah Pengangguran \\
\hline $\mathrm{Ea}$ & $\begin{array}{l}\text { Lowongan Pekerjaan Terkait Industry 4.0 } \\
\text { Yang tidak Terpenuhi }\end{array}$ \\
\hline $\mathrm{Eb}$ & $\begin{array}{l}\text { Lowongan Pekerjaan Terkait Terkait Model } \\
\text { Bisnis Baru Yang tidak Terpenuhi }\end{array}$ \\
\hline $\mathrm{Ec}$ & Pekerjaan Umum tak Terpenuhi \\
\hline & \\
$\mathrm{Ua}$ & Jumlah Pengangguran Terkait Industry 4.0 \\
\hline $\mathrm{Ub}$ & $\begin{array}{l}\text { Jumlah Pengangguran Terkait Model Bisnis } \\
\text { Baru }\end{array}$ \\
\hline $\mathrm{Uc}$ & Jumlah Pengangguran Pekerjaan Umum \\
\hline $\mathrm{Aa}$ & $\begin{array}{l}\text { Angkatan Kerja siap untuk Terkait Industry } \\
4.0\end{array}$ \\
\hline $\mathrm{Ab}$ & $\begin{array}{l}\text { Angkatan Kerja siap untuk Model Bisnis } \\
\text { Baru }\end{array}$ \\
\hline $\mathrm{Ac}$ & Angkatan Kerja siap untuk pekerjaan Umum \\
\hline $\mathrm{Atotal}$ & Angkatan Kerja Total \\
\hline $\mathrm{La}$ & $\begin{array}{l}\text { Lapangan Pekerjaan Terkait Support } \\
\text { Perubahan Industry 4.0 }\end{array}$ \\
\hline $\mathrm{Lb}$ & $\begin{array}{l}\text { Lapangan Pekerjaan untuk Model Bisnis } \\
\text { Baru }\end{array}$ \\
\hline $\mathrm{Lc}$ & Lapangan Pekerjaan Umum \\
\hline $\mathrm{Tb}$ & Pelatihan Terkait Model Bisnis Baru \\
\hline
\end{tabular}

\begin{tabular}{|l|l|}
\hline Variabel & \multicolumn{1}{|c|}{ Penjelasan } \\
\hline $\mathrm{Ta}$ & Pelatihan Terkait Industry 4.0 \\
\hline $\mathrm{M}$ & Jumlah Kebutuhan perangkat baru \\
\hline $\mathrm{Q}$ & $\begin{array}{l}\text { Jumlah Proses yang digantikan oleh teknologi } \\
\text { baru }\end{array}$ \\
\hline $\mathrm{H}$ & $\begin{array}{l}\text { Konversi antara Jumlah Proses dengan } \\
\text { teknologi baru terhadap jumlah kebutuhan } \\
\text { perangkat teknologi baru }\end{array}$ \\
\hline $\mathrm{K}$ & $\begin{array}{l}\text { Konversi antara Jumlah Perangkat Teknologi } \\
\text { Baru terhadap Kebutuhan Tenaga Manusia } \\
\text { Penunjang }\end{array}$ \\
\hline $\mathrm{B}$ & Jumlah Model Bisnis Baru \\
\hline $\mathrm{Y}$ & $\begin{array}{l}\text { Faktor Konversi antara Model Bisnis Baru dan } \\
\text { Lapangan Kerja }\end{array}$ \\
\hline $\mathrm{P}$ & Jumlah Proses Bisnis \\
\hline $\mathrm{F}$ & \% Proses yang digantikan oleh mesin \\
\hline $\mathrm{N}$ & $\begin{array}{l}\text { Perkembangan Teknologi terkait Perubahan } \\
\text { Industry 4.0 yang Masuk ke Negera }\end{array}$ \\
\hline $\mathrm{D}$ & $\begin{array}{l}\text { Faktor konversi Perkembangan Teknologi dan } \\
\text { Peran mesin }\end{array}$ \\
\hline $\mathrm{V}$ & $\begin{array}{l}\text { Perkembangan Teknologi terkait Perubahan } \\
\text { Industry 4.0 }\end{array}$ \\
\hline $\mathrm{O}$ & Keterbukaan Terhadap Teknologi \\
\hline & $\begin{array}{l}\text { Faktor Konversi antara Perkembangan } \\
\text { Teknologi dan Model Bisnis }\end{array}$ \\
\hline
\end{tabular}

Nilai akhir yang dievaluasi dalam model ini adalah jumlah pengangguran.Jumlah pengangguran dimodelkan sebagai akumulasi dari jumlah pengangguran dari berbagai sektor bidang. Mengahadapi revolusi Industri 4.0 ini,lapangan kerja dapat diklasifikasikan menjadi tiga lapangan kerja utama yaitu lapangan kerja baru untuk menunjang perubahan di industri akibat Industry 4.0. Terdapat pula lapangan kerja yang dahulu sudah ada sebelum terjadinya revolusi Industry 4.0.Serta terdapat pula lapangan kerja yang merupakan hasil dari bentuk model bisnis baru akibat perkembangan teknologi ini. Maka dari itu fungsi dari jumlah dari total pengangguran adalah pengangguran pad alapangan kerja Industry 4.0, lapangan kerja tradisional yang tidak terkait dengan Industry 4.0dan lapangan kerja dari model bisnis baru akibat perkembangan teknologi. Hal ini dapat dimodelkan menjadi sebagai berikut di mana Utotal adalah unemployment atau pengangguran total.Ua adalah jumlah pengangguran untuk sektor proses Industry 4.0. Ub adalah jumlah 
pengangguran yang terjadi akibat terbentuknya model bisnis baru.Uc adalah jumlah pengangguran pada sektor usaha umum yang belum terkait oleh perubahan Industry 4.0.

\section{Kesimpulan}

Variabel yang dapat dipertimbangan dalam pengambilan keputusan adalah tingkat keterbukaan terhadap teknologi, tingkat pelatihan terkait Industry 4.0dan tingkat pelatihan untuk model bisnis baru sebagai controllable variable. Sedangkan uncontrollable variable adalah jumlah tenaga kerja yang siap kerja, jumlah proses bisnis total, dan perkembangan teknologi Industry 4.0. Kaitan model tersebut dijelaskan menggunakan Influence Diagram.Influence diagram yang dirancang ini dapat dikembangkan menjadi model matematika dan model simulasi. Dapat pula dilakukan pengembangan penelitian untuk memepalajari efek peningkatan perkembangan teknologi Industry 4.0yang meningkatkan pertumbuhan ekonomi yang mana meningkatkan total aktivitas proses bisnis.

\section{Daftar Referensi}

[1] A. Osterwalder and Y. Pigneur.2010. Business model generation: a handbook for visionaries. game changers. and challengers. John Wiley \& Sons.

[2] R. H. Mabry and A. D. Sharpin. 1986. "Does more technology create unemployment? (Vol. 68)." Cato Institute.

[3] R. M. Solow. 1965. "Technology and unemployment.." The Public Interest. (1). p. 17.

[4] M. N. Georgiou.1965. "Does Technology Cause Unemployment?".

[5] P. Dungan and A. Younger, "Dungan, P., \& Younger. A. 1985. New technology and unemployment: A simulation of macroeconomic impacts and responses in Canada.." Journal of Policy Modeling. 7(4). pp. 595-619.

[6] D. F. Noble, 1995. "Progress without people: New technology. unemployment. and the message of resistance.." Between the Lines.

[7] J. Danaher. 2017. "Will life be worth living in a world without work? Technological unemployment and the meaning of life.." Science and engineering ethics. 23(1). pp. 41-64.

[8] G. Casey. 2017. "Technology-Driven Unemployment".

[9] D. R. Davis. 1998. "Technology. unemployment. and relative wages in a global economy.." European Economic Review. 42(9). pp. 1613-1633.

[10] D. T. Mortensen and C. A. Pissarides. 1999. "Unemployment responses to "skill-biased'technology shocks: the role of labour market policy.." The Economic Journal. 109(455). pp. 242-265.

[11] A. Sen. 1997. "Inequality. unemployment and contemporary Europe.." Int'l Lab Rev.. pp. 136. 155.

[12] M. Ford. 2015. "The rise of the robots: Technology and the threat of mass unemployment.." Oneworld Publications.

[13] D. N. P. Murty, N. W. Page and E. Y. Rodin. 1990. Mathematical modelling: a tool for problem solving in engineering. physical. biological. and social sciences. Oxford: Pergamon Press.

[14] R. Aurachman and A. Y. Ridwan. 2016. "Perancangan Model Optimasi Alokasi Jumlah Server untuk Meminimalkan Total Antrean pada Sistem Antrean Dua Arah pada Gerbang Tol." JRSI (Jurnal Rekayasa Sistem dan Industri). vol. 3. no. 2. pp. 25-30.

[15] H. D. D. McNickle and S. Dye. 2012. Management science: decision-making through systems thinking. Palgrave macmillan. 
Jurnal Teknologi dan Manajemen Industri, Vol. 4 No. 2, Agustus 2018 Pascasarjana Institut Teknologi Nasional Malang

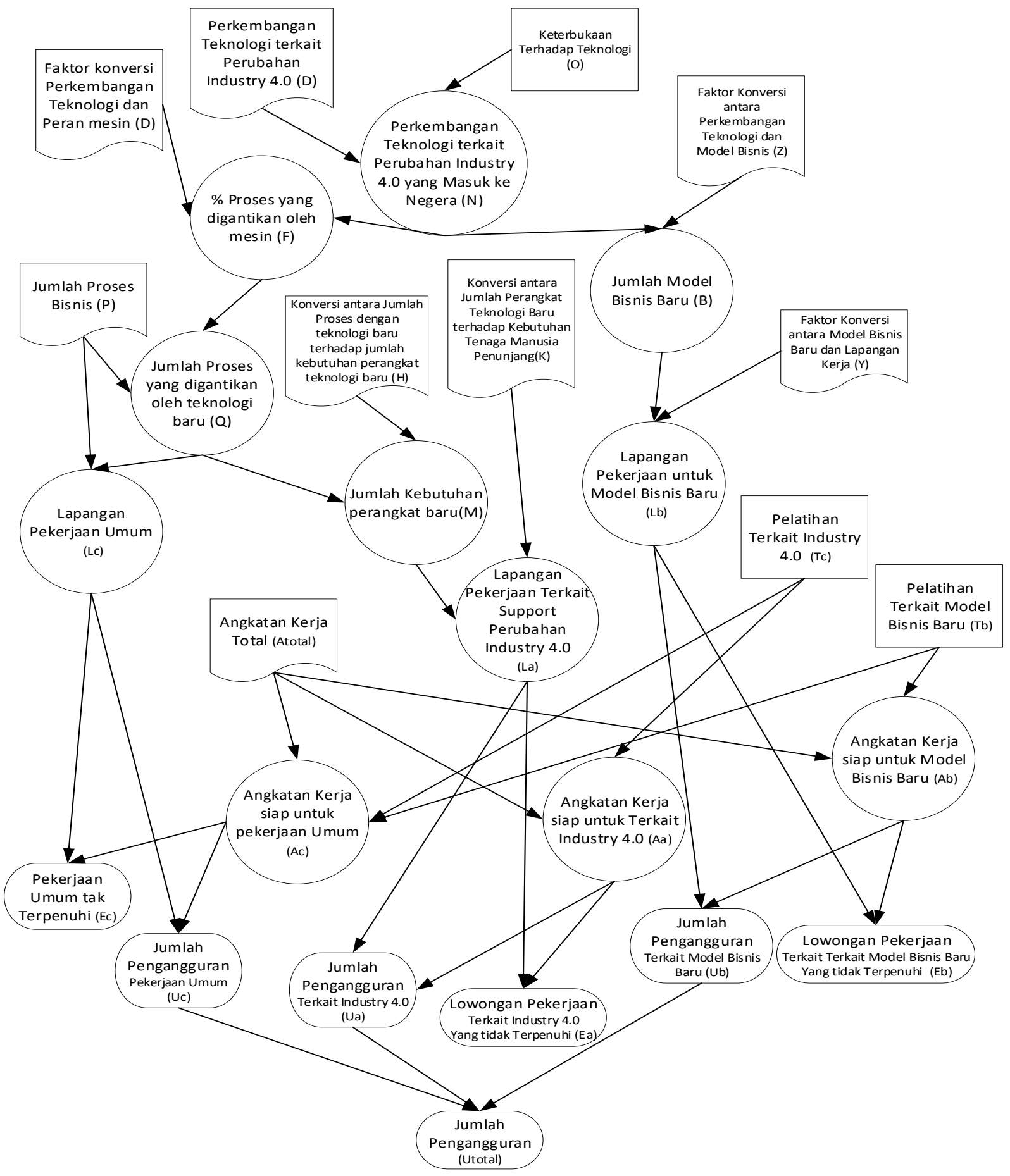

Gambar 1Influence Diagram Antara Jumlah Pengangguran dan Perkembangan Teknologi 